$$
\begin{aligned}
& S 59 \\
& . E 4
\end{aligned}
$$



Lextract from the 10th Annual Report of the Indiana Agricultural Experiment Station for 1897.]

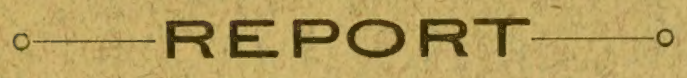

OF THE

\section{Botanical Department.}

By J. O. ARTHUR.

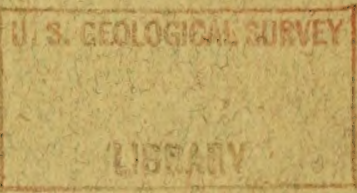

DIETRIEUTEDAARIL, 18B日.

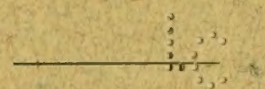

INDIANAPOLIS :

WM. B. BURFORD; CONTRACTOR FOR STATE PRINTING AND BINDING. 


$$
5_{5}^{5}
$$

By trantitor nrt 2,9 10nर́

$\therefore \vdots$ 


\section{REPORT OF THE BOTANICAL DEPARTMENT.}

To C. S. Plumb, Director:

Sir-The work of the Botanical Department of the Station for the year 1897 has been a continuation of that of the previous year without serious interruption, there having been no change in the personnel of the department or in its policy. At the close of the previous year the rooms of the department were renovated and treated with paint, and an additional room provided, having 300 square feet of floor space, to be especially devoted to laboratory instruction. This improvement has added both to the convenience and the efficiency of the experimental work, by the partial withdrawal of studentsfrom the general laboratory, especially for the five months from January to May, inclusive, during which University classes in vegetable physiology, ecology and pathology receive instruction.* A general account of the equipment of the department was given in the report of last year, which remains equally applicable at the present time.

\section{POTATO.}

It is a matter for congratulation that the efforts of the department in the study of the potato scab, and especially the attempt to provide a cheap, safe and convenient remedy, have met with the most signal success. Experiments were begun in the greenhouse in the winter of 1895-6 and earried to completion in the field during the following summer, which led to the conclusion that formalin was an effective fungicide against scab, and furthermore, that it met the above-named requirements of cheapness and convenience, and particularly of safety. What had been wanted was a remedy possessing the good qualities of corrosive sublimate, but without its deadly poisonous properties. Such a remedy has been found in formalin.

The results of the trials of 1896 were first published in a newspaper bulletin in February of the present year (1897), in order to give the farming public the benefit of the discovery in time to make

\footnotetext{
* Much of the botanical instruction provided by Purdue University is given at the Iaboratories in Science Hall by Professor Stanley Coulter and his associates, especially in general. structural and systematic botany, histology, fermentation, bacteriology, adn other special subjects.
} 
it of service in the management of the year's crop. The full report of the experiments, which had been prepared at the close of the previous season, was not printed until June, and in a limited edition. Persons desiring it (Bulletin 65) are expected to make application to the Director of the Station. It will be sent to such persons prepaid and free of charge.

The bulletin on "Formalin for Prevention of Potato Scab" (No. 65 ) consists of 20 pages and two plates, and gives the history of the subject, the results obtained at the Station, the results obtained by others, some account of the nature of formalin and specific directions for its use. It also discusses the relation of soil moisture to the increase of scab, and details an important method for the estimation of the injury to the crop.

The department carried on no tests of formalin during 1897, but hoped that it would be tried by many potato growers under sufficiently diverse conditions to gauge its value as a serviceable fungicide for general use. All reports so far received from growers agree in commending the remedy as meeting every reasonable requirement and fully affirming the good points claimed for it in the bulletin. Two letters are selected from the correspondenceone from Nebraska and the other from Massachusetts-which not only represent widely different sections of the country, but add some items of practical interest worthy of record.

Mr. B. B. Rice, of Grand Island, Neb., writes, under date of October 27, 1897, that he treated 21 bushels of Early Ohio potatoes. The seed tubers were "large, quite free from scab, having been selected from the scabby crop of last year." He purchased a one-pound bottle of formalin (\$1.25). Two barrels were used, and into each was put (by guess) 15 gallons of water and one-half the formalin. A bushel of uncut potatoes contained in a sack was dropped into each barrel, and after remaining a time, another bushel was put in, the same solution being used over and over until all were treated. The course of treatment was as follows:

One bushel in each barrel 3 times for 2 hours......6 bushels One bushel in each barrel 2 times for $2 \frac{1}{4}$ hours. . . . . 4 bushels One bushel in each barrel 2 times for $2 \frac{1}{2}$ hours......4 bushels One bushel in each barrel 2 times for $23 / 4$ hours.....4 bushels Three-fourths bushel in each barrel 2 times

for 3 hours .......................... bushels 
He goes on to say (and this is a specially valuable contribution to the subject): "I could detect no difference in the amount of scab in the crop from seed treated first or last." He says, further: "I think now that the seed, although quite clean, should have been washed before it was placed in the solution, but I did not know it at the time the treatment was given. The 21 bushels were planted on four acres. One-third the field was well cared for; there the tubers were quite free of scab. The rest was very weedy and the potatoes a little more scabby. Yet on the whole the crop was not more than one-third as scabby as it was last year. The average yield was over 80 bushels per acre. I think your remedy is valuable and that it has benefited me, for the neighbor from whom I bought my seed a year ago did not doctor his potatoes last spring, and his crop this fall is very scabby - three times as bad as mine. Both fields of potatoes were planted in fresh soil-land not previously used for potatoes."

The other letter from which I wish to quote was received from Mr. Frank H. Goodhue, of North Andover, Mass., dated December 18, 1897. He writes: "The land I used for the experiment, about three-fourths of an acre, had been in mowing for 13 consecutive years. I broke the sod about nine inches deep, then harrowed thoroughly, furrowed three feet apart and put seed about one foot apart in the hills.

"I used 800 pounds Stockbridge potato fertilizer and 500 pounds Standard potato fertilizer, but used no stable manure. I put a large handful of fertilizer in each hill, mixed it thoroughly with the soil, then dropped the seed, covering it with about two inches of soil, scattered another handful of fertilizer over it, and finished off with some more soil. In order that the fertilizer might not cause the tubers to vary, the same kind was used on treated and untreated seed of each variety.

"The land was nearly level, only a slight rise on the west side; soil moist, but not wet. As far as moisture was concerned, the soil was alike on both treated and untreated seed. There was not a tree or building near the field to interfere.

"I planted four bushels each of Somerset and Rose Standish and also a few potatoes of Early Harvest and Early Fortune, and also some of Dandy and Old Merino, one-half of each variety being treated with formalin. The smaller lots were subjected only two 
hours to formalin, but the Somerset and Rose Standish were treated three hours. All of the seed was nearly free from scab. In order to be as accurate as possible, I put only three rows of untreated seed between the rows of treated seed.

"The seed was treated, then dried and planted about a week after treatment. Being very busy, I did not empty the formalin for eight days after using, and on doing so I found two tubers of the Somerset variety in the bottom of the eask. I planted them along with the Rose Standish that were not treated, making two hills of them, so that I would know them at harvest time. When we came to them I dug them myself. They were large, smooth and the cleanest potatoes I have ever dug from the soil.

"All the treated seed produced clean, smooth and handsome tubers, with not a rotten one among them, while the untreated were rather inferior in size, with many tubers considerably scabbed, say one-third of the surface, and about 3 per cent. were rotten.

"I think, with eight ounces of formalin to 15 gallons of water, that four hours' treatment are better than two hours. I am also inclined to believe the remedy is to some extent a preventive for rot."

Both of these reports indicate the important character of this remedy and the ease of its application. As shown by Mr. Groodhue, the length of time the seed tubers are kept in the solution does not noticeably affect their growth, especially if they have not sprouted too much, and a longer immersion kills the germs of the scab disease more completely. It is probable that the repeated use of the same solution could not, as a rule, be safely carried so far as practiced by Mr. Rice, but a half dozen times might still give good results, if the tubers were free from dirt and the periods of immersion were sufficiently prolonged. The report of Mr. Goodhue is especially to be commended for the careful way in which the treated and untreated material were subjected to uniform conditions. It will be a most important point gained when eultivators generally learn to try new remedies and methods of all kinds with a control for comparison, as in this case.

\section{LETTUCE.}

Several crops of lettuce have been grown in the greenhouse of the department during the last two years, but the most important part of the work reached completion in 1897. The results have 
been embodied in a bulletin of 20 pages and two plates, prepared by the Assistant Botanist, Mr. William Stuart. This bulletin has been sent to those thought to be interested in the subject. It can be obtained by others upon application to the Director. A brief statement of the main facts, unaccompanied by tables, has been prepared and printed by the Station in a bulletin bearing date of October, 1897.

The results obtained embrace some important items for the cultivation of indoor lettuce. By the use of commercial fertilizers the yield of the benches was increased more than three and a half times, when properly combined and applied; but with injudicious use their application decreased the yield. A moderately thick planting was found, contrary to expectation, to produce a heavier crop per square foot of bench than thinner planting. The use of flower pots to secure a ball of earth around the roots when marketed, and also for convenience in handling, was found to invariably lessen the yield. A method of obtaining the advantages of the pot with only the slightest eheck to growth is recommended in the bulletin, based upon the result of the experiments. The crops obtained by methods considered commendable were of the highest market value in both amount and quality.

\section{CORN.}

Observations and studies of corn smut have been continued during the year. The inoculation of young plants in second leaf with formation of smut pustules was successfully accomplished during October in the greenhouse by spraying with germinating spores. All the results and facts obtained will eventually be brought together in a bulletin.

\section{BEET.}

Further researches into the nature of the peculiar sugar-destroying disease of thesugar beet, some account of which has already been published in Bulletin No. 39 (April, 1893), and there ascribed to a specific kind of parasitic bacteria, have been prosecuted, most of the work being done by Miss Clara Cunningham as a part of her University studies. The bacterial nature of the disease, a point which has been called in question, has been confirmed, and many 
details of the life history of the parasite have been worked out. Excellent photographs have been secured, showing clearly the characteristic appearance of diseased beets, which will be used to illustrate the next contribution to the subject.

\section{ROSE.}

The use of different commercial fertilizers in growing the rose for cut flowers has been continued from last year. The same plants that were used last year, having been wintered in a cold pit, were used again without repotting. Nost of the cans received an additional amount of the same fertilizers used the preceding season, a few cans being reserved, however, for special treatment. The results of the season confirm in the main those of last year.

In order to test in the open field the results obtained in the vegetation house, a piece of ground was planted with 14 varieties of hardy and semi-hardy roses. They were from two-and-a-half-inch pots, twelve of each variety. Nothing of importance was learned the present season, however, as the plants did not become sufficiently well established to respond noticeably to the presence of fertilizers.

This set of experiments is especially under the charge of the Assistant Botanist.

\section{CINERARIA.}

The plants of this attractive flower, which had been brought into bloom in December, 1896, continued to fill the greenhouse to its full capacity through January, February, March and April with a rich and brilliant display of flowers. Many of the plants bore more than 300 flowers each, and as specimen plants or in mass were universally admired. About 30 ladies of the city were asked to coöperate with the Station in testing the adaptability of the plants to decorative purposes under ordinary household conditions. They received plants and cared for them as they thought best until no longer decorative, reporting upon the frequency of watering, amount applied, temperature of the rooms, extent of exposure to sunlight, time when the first flowers failed and time when the plant became unattractive. The trials resulted most satisfactorily, and, 
taken altogether, much data has been accumulated upon the method of handling the plant and its adaptability to household decoration, which it is hoped may be early cmbodied in a bulletin.

\section{FOOD OF PLAN'TS.}

Of all the problems in the physiology of plants, probably none so directly bears upon the methods and profits of intensive farming and high eultivation generally as the application to the soil of barnyard and commercial fertilizers for the purpose of supplying food for the growing crop. Great advance has been made since the days of Liebig, the great promoter of high-grade husbandry, in the profitable use of fertilizers and in a knowledge of the requirements of different crops, and yet the practice remains largely empirical.

$\Lambda \mathrm{n}$ exact knowledge of the kinds of food required by each kind of plant, of the method of its assimilation and of the apportiomment of it within the plant to the building up of the different organs, has been exceedingly difficult to acquire. From Roman days, when agriculture was held in such high esteem that it was considered a worthy subject for the pen of the greatest pocts, until the present time, little of a fundamental character has been added to our lnowledge of the subject by the open-field method. Field experiments properly follow, but cannot take precedence, in providing the initial facts upon which rational husbandry should find a sure foundation. A great impetus was given to the elementary study, when, in 1860, the modern method of water cultures was introduced, by which, among other things, the now well-known fact that the carbon of the plant is obtained from the air and not from the soil was first definitely establisher. Since then cultures in water, sand and artificial earths and in restricted amounts of soil, kept under conditions controlled by the experimenter, have yielded the inost valuable additions to our knowledge.

With a view of promoting a better understanding of some of the questions connected with the food and food supply of plants, the department has carried on studies in pot and bench cultures since the erection of the regetation house, in 1893. Oats, wheat, corn, potatoes, buckwheat, roses, lettuce and certain weeds have been used in the experiments. Some of the data, discussed from the commercial side, was recently presented in the lettuce bulletin, 
referred to above, but the bulk of the results yet remain unpublished. It is proposed to continue these studies, with the hope that they may add some facts of importance to exact knowledge, and in particular, furnish data for improved and more economical ways of increasing yield by means of fertilizers.

\section{SIZE OF SEED.}

Experiments have been instituted from time to time, and the results partly published, which have established beyond doubt that the larger seeds of any particular kind of plant give a larger (rop than the smaller seeds, both being grown under the same conditions. The experiments are now being continued in a somewhat modified form to ascertain how far the increase can be expected to extent, lyy selecting the largest seeds from each successive generation. Peas and beans are used, an account being kept of the size of the reeds sown each time, and of the size of the resulting plant, as well as of the number and size of the resulting seeds. It is, in fact, an attempt to ascertain the law of increase in size when hromght about solely ly the selection of the largest seerds thromgh a series of generation.

\section{SUB-IVATERING FOR GREENHOUSES.}

()f the rarious falctors influencing the growth of plants, none is of greater moment than the control of the water supply. It has been nutil recently almost an axiom in culture under glass that an atmosphere heavily charged with moisture was a prime essential to sucres. To secure this condition excessive watering and sprinkling of the surface was resorted to. The plants being grown in shallow hemelues or in pots often suffered for moisture in the soil about the roots when the surface soil and the atmosphere were excessively moist.

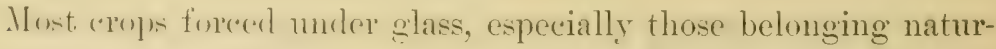
ally to temperate climates, such as tomatoes, lettuce, radish, cauliflower, carnations, roses, chrysanthemums, etc., thrive best with a moderately moist and well-acrated soil and rather dry atmosphere. The last condition is especially needed to promote a rapid movement of water through the plant, by which the food materials taken 
from the soil are transported to the upper parts and mate arailable for growth. In some cases the eontinued health of the plants depends upon the strength of this transpiration stream.

This method of sub-watering supplies moisture readily to the? part of the soil where it is most needed; it keeps the soil friable and well aerated; it prevents the packing of the surface soil and retards the accumulation of weeds and slime; it promotes a drier atmosphere, especially in contact with the plants, and removes mueh of the danger of invasion by molds, rots and other fungous diseases by permitting the surface of the foliage to be kept dry, and in many ways it brings about cultural conditions better than those obtained by the old methods.

The crops grown with this system of watering are larger and of better quality than usually secured, and it is believed that the results of our trials, especially during 1897 , warrant its recommendation for commercial houses, although the first cost is considerable (13 cents per square foot in the trial bench at the Station). The system has been explained, with illustrations, in the bulletin on indoor lettuce (No. 66), previously referred to.

\section{OUTSIDE STORAGE.}

For several years the department was without suitable means of carrying tubers, bulbs and dormant plants through the winter. In the fall of 1896 an outside storage pit was construeted that has met the demands so fully that it is worthy of brief mention. 'There: is nothing novel about the method, hut its eheapness and effieiency are probably not generally recognized.

The pit consists of a cellar nine by fifteen feet, two-thirds sunken below the general surface of the ground, with five hotbed sashes forming the north slope of the roof, and the rest of the roof and the sides banked with earth and layers of straw. A bulkhead entrance with inner door and extra banking of straw in the coldest weather kept the pit from freezing during the winter of 1896-7. The bench was formed by leaving a ledge of earth, and the roof and side supports were marle from the roughest material. The total cost of the structure was very small.

Perle des Jardin and Kaiserin Augusta Victoria roses, altogether over 100 pots, were placed in the pit November 25 and were 
taken ont $\Lambda$ pril 1, every plant in excellent condition, many of them still retaining much of their foliage. A few potatoes were also stored in the pit, and were kept in perfect condition. It is again being used to its full capacity for the winter season of 1897-8.

This is a cheap and efficient means of winter storage, and its possibilities deserve to be kept in mind. The department could econnnically use a much larger pit than the present one, and the purposes to which it is put might profitably be much extended.

Respectfully submitted,

J. C. ARTHUR, Botanist. 

LIBRARY OF CONGRESS

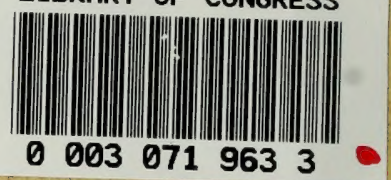

